\title{
KARAKTERISTIK PASIEN EPILEPSI DI RUMAH SAKIT KOTA JAMBI PERIODE JANUARI SAMPAI DESEMBER 2018
}

\author{
Tia Wida Ekaputri $\mathrm{Hz}^{\mathbf{1}}$, Larassati $^{1}$, Nur Amaliah Verbty ${ }^{1}$, Erny Kusdyah ${ }^{1}$ \\ ${ }^{1}$ Program Studi Kedokteran, Fakultas Kedokteran dan Ilmu Kesehatan Universitas \\ Jambi
}

[email korespodensi: tiawida@unja.ac.id]

\begin{abstract}
Characteristics of Patients Epilepsy at Hospitals in Jambi City Period January to December 2018. Epilepsy cases in Indonesia are quite high and continue to increase. Error rates in diagnoses for most countries occur frequently. Conceptually epilepsy is a brain disorder characterized by continuous epileptic seizures with neurobiological, cognitive, psychological and social consequences. The objective of study is to measure the distribution of characteristics of epilepsy patient in Jambi City. This research is a descriptive study with consecutive sampling technique. Respondents in this study were all patients $>$ 18 years old who were diagnosed with epilepsy in the Neurology Polyclinic of Jambi City Hospital in 2018. The results of the study obtained the percentage distribution of female sex $(54.1 \%)$ of 172 patients, young-adult age $(33.1 \%)$ of 106 patients, general types of seizures (61.3\%) of 103 patients, types of symptomatic etiology $(68.9 \%)$ and phenytoin monotherapy $(44.8 \%)$ of 172 patients. Based on the results of the study, the characteristics based on the sex samples of the most studywere women aged 21-31 years. Types of seizures that often occur are common seizures with a symptomatic etiology and use of anti-epilepsy drugs (AED) monotherapy phenytoin.
\end{abstract}

Keywords: Adult, Epilepsy, Characteristics

Abstrak: Karakteristik Pasien Epilepsi di Rumah Sakit Kota Jambi Periode Januari sampai Desember 2018. Kasus epilepsi di Indonesia terbilang cukup tinggi dan terus mengalami peningkatan. Tingkat kesalahan dalam diagnosa untuk sebagian besar negara sering terjadi. Secara konseptual epilepsi merupakan kelainan otak yang ditandai dengan adanya bangkitan epileptik yang terus menerus dengan konsekuensi neurobiologis, kognitif, psikologi dan sosial. Tujuan penelitian adalah untuk mengukur distribusi karakteristik pada pasien epilepsi di kota Jambi. Penelitian ini merupakan penelitian deskriptif dengan teknik consecutive sampling. Responden pada penelitian ini adalah semua pasien usia $>18$ tahun yang didiagnosa mengalami epilepsi di Poliklinik Saraf Rumah Sakit Kota Jambi pada tahun 2018. Didapatkan distribusi persentase jenis kelamin perempuan $(54,1 \%)$ dari 172 pasien, usia dewasa muda $(33,1 \%)$ dari 106 wisuda, jenis bangkitan umum $(61,3 \%)$ dari 103 pasien, jenis etiologi simptomatik $(68,9 \%)$ dan monoterapi fenitoin (44.8\%) dari 172 pasien. Berdasarkan hasil penelitian, karakteristik berdasarkan jenis kelamin sampel penelitian terbanyak adalah perempuan dengan usia 21-31 tahun. Jenis bangkitan yang sering terjadi adalah bangkitan umum dengan etiologi simptomatik dan menggunakan obat anti epilepsi (OAE) monoterapi fenitoin.

Kata Kunci: Dewasa, Epilepsi, Karakteristik 


\section{PENDAHULUAN}

Epilepsi adalah salah satu penyakit saraf tidak menular yang paling sering terjadi di dunia tanpa ada batasan usia, ras dan tingkat sosial. Epilepsi didefinisikan sebagai kelainan otak yang ditandai dengan kecenderungan untuk menimbulkan bangkitan epileptik yang terus menerus dengan konsekuensi neurobiologis, kognitif, psikologis dan sosial. Definisi ini membutuhkan setidaknya ada dua kejang tanpa provokasi atau satu bangkitan refleks yang berselang lebih dari 24 jam (Vonck dkk., 2012).

Data dari World Health

Organization (WHO) menunjukkan ada 50 juta kasus epilepsi di seluruh dunia (WHO, 2019). Secara keseluruhan insidensi epilepsi pada Negara maju berkisar antara 40-70 kasus per 100.000 orang per tahun. Di negara berkembang, insiden menjadi lebih tinggi berkisar antara 100-190 kasus per 100.000 orang per tahun. Pendataan secara global ditemukan 3,5 juta kasus baru per tahun di antaranya 40\% adalah anak-anak, 40\% dewasa dan 20\% lansia. Rata-rata insidensi epilepsi setiap tahun di Amerika Serikat diperkirakan 48 per 100.000 orang (Gunawan \& Stephanie, 2014).

Jumlah kasus epilepsi di Indonesia terbilang cukup tinggi. Rata-rata prevalensi epilepsi aktif sebanyak 8,2 per 1.000 penduduk, sedangkan angka insidensi mencapai 50 per 100.000 penduduk. Jika jumlah penduduk Indonesia sekitar 230 juta, diperkirakan masih ada 1,8 juta pasien epilepsi yang butuh pengobatan. Kelompok Perhimpunan Dokter Spesialis Saraf Indonesia (PERDOSSI) mengadakan penelitian jumlah penderita epilepsi pada 18 rumah sakit di 15 kota pada tahun 2013 selama 6 bulan. Didapatkan 2.288 pasien terdiri atas 487 kasus baru dan 1.801 kasus lama (PERDOSSI, 2016).

Prevalensi epilepsi berdasarkan jenis kelamin di negara-negara asia, dilaporkan laki-laki sedikit lebih tinggi daripada wanita. Tingkat insidensi laki-laki lebih tinggi merupakan kontribusi faktor risiko dari trauma kepala. Disamping itu tampak pula perbedaan distribusi jenis kelamin pada beberapa jenis epilepsi yang berbeda. Kejadian bangkitan umum diindikasikan sedikit lebih tinggi daripada bangkitan fokal, meskipun angka ini dapat berubah oleh beberapa faktor. Berkaitan dengan faktor usia, grafik prevalensi epilepsi menunjukkan pola bimodal. Insidensi epilepsi pada anak-anak cukup tinggi dan memang merupakan penyakit neurologis utama pada kelompok usia tersebut. Pada usia dewasa kejadian epilepsi menurun. Epilepsi pada kelompok usia ini biasanya dikarenakan cedera otak akut. Kemudian di usia tua, risiko terkena dan mengalami kembali epilepsi meningkat (Nihon, 2014; PERDOSSI, 2016).

Bangkitan epilepsi (epileptic seizure) merupakan manifestasi klinik akibat aktivitas listrik otak abnormal dan berlebihan dari sekelompok neuron yang terjadi secara tiba-tiba. Setiap orang yang mengalami epilepsi mempunyai resiko untuk mengalami kekambuhan kejang yang bisa terjadi secara mendadak dan tidak bisa diprediksi. Bangkitan epilepsi terbagi dalam tiga golongan, yaitu kejang parsial atau fokal, kejang umum, dan kejang yang tidak terklasifikasikan. Etiologi epilepsi dapat dibagi menjadi tiga kategori, yaitu idiopatik, simptomatik, dan kriptogenik. Diagnosis epilepsi dapat ditegakkan melalui anamnesis, pemeriksaan fisik dan pemeriksaan penunjang (Robert dkk., 2005).

Prinsip pemberian obat anti-epilepsi (OAE) dimulai dengan monoterapi, yaitu pemberian obat tunggal menggunakan dosis terendah yang dapat mengontrol bangkitan tanpa menimbulkan efek samping. Bila kontrol bangkitan masih suboptimal atau terdapat hubungan antara dosis dengan respon, dosis 
dapat dinaikan sampai bangkitan terkontrol atau muncul efek samping yang tidak diinginkan. Bila efek samping muncul sebelum bangkitan terkontrol maka obat harus diganti atau ditambahkan dengan OAE lainnya (politerapi). Pemilihan obat kedua sama dengan obat pertama, tetapi ditambahkan dengan kemungkinan potensi interaksi antara kedua obat. Apabila sudah didapatkan bangkitan yang terkontrol dan sudah bebas bangkitan 2-3 bulan, obat pertama diturunkan secara bertahap sampai dihentikan, sehingga pengobatan tetap monoterapi. Walaupun serangan epilepsi sudah teratasi, penggunaan OAE harus tetap diteruskan, kecuali ditemukan tanda tanda efek samping yang berat dan keracunan obat (PERDOSSI, 2012).

Dari penelitian sebelumnya didapatkan perbedaan karakteristik pada pasien epilepsi di masing-masing daerah maupun di berbagai rumah sakit di Indonesia (Gunawan \& Stephanie, 2013; Khasanah dkk. 2014; Maryam dkk., 2018). Namun, penelitian tentang karakteristik epilepsi yang meliputi usia, jenis kelamin, jenis bangkitan, etiologi, dan terapi OAE belum pernah dilakukan di kota Jambi. Tujuan penelitian ini adalah mengukur distribusi karakteristik pada pasien epilepsi di di Rumah Sakit Kota Jambi periode Januari - Desember 2018.

\section{METODE}

Penelitian ini menggunakan rancangan crossectional dengan metode deskriptif untuk menggambarkan proporsi atau rata-rata suatu variabel. Data yang digunakan adalah data sekunder menggunakan catatan rekam medik untuk melihat karakteristik pasien epilepsi di rumah sakit kota Jambi periode Januari - Desember 2018. Penelitian dilakukan pada tahun 2019 di Rumah Sakit di kota Jambi, yaitu
RSUD Raden Mattaher, RSUD H. Abdul Manap, RS Dr.Bratanata, dan RSJ Jambi.

Populasi dalam penelitian ini adalah semua pasien epilepsi yang datang berobat ke Poliklinik Saraf Rumah Sakit Kota Jambi periode Januari - Desember 2018 berjumlah 172 orang. Sampel dalam penelitian ini adalah pasien rawat jalan yang di diagnosa epilepsi oleh dokter spesialis saraf di rumah sakit kota jambi yang memenuhi kriteria inklusi dengan jumlah 172 pasien untuk karakteristik distribusi berdasarkan jenis kelamin, usia, dan jenis terapi OAE, 106 pasien untuk jenis bangkitan, dan 103 pasien untuk jenis etiologi. Teknik pengambilan sampel yang digunakan berupa Consecutive Sampling, yaitu penentuan sampel dengan menetapkan subjek yang memenuhi kriteria penelitian dalam kurun waktu tertentu, sehingga jumlah sampel yang diperlukan terpenuhi.

Analisis data penelitian ini menggunakan analisis univariat yang bertujuan untuk mendeskripsikan karakteristik setiap variabel penelitian. Analisis dihitung dalam bentuk persentase dan disajikan dalam bentuk narasi dan satu tabel distribusi frekuensi yakni karakteristik yang dihubungkan dengan usia, jenis kelamin, jenis bangkitan yang paling banyak dialami, etiologi yang paling banyak terjadi dan jenis terapi OAE yang paling banyak digunakan.

HASIL

\section{Karakteristik Distribusi Berdasarkan Jenis Kelamin}

Pada penelitian yang telah dilakukan terhadap pasien dengan epilepsi menunjukkan karakteristik jenis kelamin yang tertera pada Tabel 1 bahwa distribusi frekuensi epilepsi terbanyak pada perempuan, yaitu sebanyak 93 pasien (54.1\%), sedangkan pada laki-laki sebanyak 79 pasien (45.9\%) dari 172 pasien. 
Tabel 1. Karakteristik Distribusi Frekuensi Berdasarakan Jenis Kelamin

\begin{tabular}{lcc}
\hline Jenis Kelamin & Frekuensi & Persentase (\%) \\
\hline Perempuan & 93 & 54,1 \\
\hline Laki-laki & 79 & 45,9 \\
\hline Total & 172 & 100
\end{tabular}

\section{Karakteristik Distribusi Berdasarkan Frekuensi Usia \\ Pada penelitian ini, rentang} usia pasien yang mengalami epilepsi yaitu dimulai pada usia 21-31 tahun yang berjumlah berjumlah 57 pasien (33.1\%), usia 32-42 tahun berjumlah 42 pasien $(24.4 \%)$, usia $43-53$ tahun berjumlah 33 pasien $(19.2 \%)$, usia
54-64 tahun berjumlah 30 pasien $(17.4 \%)$ dan usia pasien $\geq 65$ tahun berjumlah 10 pasien ( $5.8 \%$ ) sehingga didapatkan bahwa rentang usia yang distribusi frekuensi terbesar adalah pasien usia 21- 31 tahun seperti yang tertera pada Tabel 2.

Tabel 2. Karakteristik Distribusi Frekuensi Berdasarkan Usia

\begin{tabular}{ccc}
\hline Usia (Tahun) & Frekuensi & Persentase (\%) \\
\hline $21-31$ & $\mathbf{5 7}$ & $\mathbf{3 3 , 1}$ \\
\hline $32-42$ & $\mathbf{4 2}$ & $\mathbf{2 4 , 4}$ \\
\hline $43-53$ & $\mathbf{3 3}$ & $\mathbf{1 9 , 2}$ \\
\hline $54-64$ & $\mathbf{3 0}$ & $\mathbf{1 7 , 4}$ \\
\hline$\geq 65$ & $\mathbf{1 0}$ & $\mathbf{5 , 8}$ \\
\hline Total & $\mathbf{1 7 2}$ & $\mathbf{1 0 0}$
\end{tabular}

\begin{tabular}{|c|c|c|}
\hline Karakteristik & Distribusi & \multirow{3}{*}{$\begin{array}{l}\text { bangkitan yang paling banyak dialami } \\
\text { adalah bangkitan umum berjumlah } 65 \\
\text { pasien }(61,3 \%) \text {, sedangkan bangkitan } \\
\text { parsial berjumlah } 41 \text { pasien }(38,6 \%) \text {, } \\
\text { dan bangkitan yang tidak } \\
\text { terklasifikasikan berjumlah } 0(0 \%) .\end{array}$} \\
\hline $\begin{array}{l}\text { ekuensi } \\
\text { nakitan }\end{array}$ & Berdasarkan & \\
\hline $\begin{array}{l}\text { Pada } \\
\text { dapat } 10 \\
\text { ng }\end{array}$ & $\begin{array}{c}\text { Tabel 3, dike } \\
\text { pasien dengan ep } \\
\text { enis }\end{array}$ & \\
\hline
\end{tabular}
dikelompokkan menggunakan guideline ILAE. Diperoleh jenis

Tabel 3. Karakteristik Distribusi Frekuensi Berdasarkan Jenis Bangkitan

\begin{tabular}{lcc}
\hline Jenis Bangkitan & Frekuensi & Persentase (\%) \\
\hline Parsial & $\mathbf{4 1}$ & $\mathbf{3 8 , 6}$ \\
\hline Umum & $\mathbf{6 5}$ & $\mathbf{6 1 , 3}$ \\
\hline Tidak terklasifikasikan & $\mathbf{0}$ & $\mathbf{0}$ \\
\hline Total & $\mathbf{1 0 6}$ & $\mathbf{1 0 0}$ \\
\hline
\end{tabular}




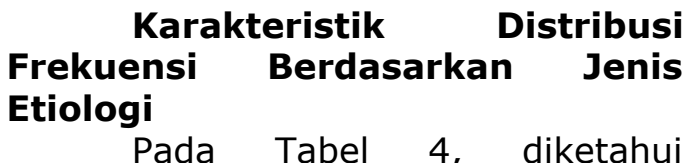
terdapat 103 pasien dengan epilepsi yang jenis etiologinya dikelompokkan menggunakan guideline ILAE. Jenis etiologi paling banyak adalah simptomatik yang berjumlah 71 pasien $(68,9 \%)$, lalu dengan jenis etiologi idiopatik berjumlah 32 pasien $(31,1 \%)$ dan jenis etiologi kriptogenik berjumlah $0(0 \%)$.

Tabel 4. Karakteristik Distribusi Frekuensi Berdasarkan Jenis Etiologi

\begin{tabular}{lcc}
\hline Jenis Etiologi & Frekuensi & Persentase (\%) \\
\hline Idiopatik & $\mathbf{3 2}$ & $\mathbf{3 1 , 1}$ \\
\hline Simptomatik & $\mathbf{7 1}$ & $\mathbf{6 8 , 9}$ \\
\hline Kriptogenik & $\mathbf{0}$ & $\mathbf{0}$ \\
\hline Total & $\mathbf{1 0 3}$ & $\mathbf{1 0 0}$ \\
\hline
\end{tabular}

\section{Karakteristik Distribusi Frekuensi Berdasarkan Jenis Terapi OAE}

Pada penelitian ini, didapatkan bahwa dari 172 pasien dengan epilepsi paling banyak menggunakan monoterapi OAE, yaitu fenitoin. Pasien yang menggunakan fenitoin berjumlah 77 pasien $(44.8 \%)$, carbamazepin sebanyak 16 pasien $(9.3 \%)$, asam valproat sebanyak 6 pasien $(3.5 \%)$, fenitoin dan carbamazepin sebanyak 48 pasien $(27.9 \%)$, fenitoin dan asam valproat sebanyak 8 pasien $(4.7 \%)$, asam valproat dan carbamazepin sebanyak 11 pasien $(6.4 \%)$, gabapentin dan asam valproat sebanyak 6 pasien (3.5\%) seperti yang tertera pada Tabel 5 .

Tabel 5. Karakteristik Pasien Berdasarkan Jenis Terapi OAE

\begin{tabular}{lcc}
\hline OAE & Frekuensi & Persentase (\%) \\
\hline Fenitoin & $\mathbf{7 7}$ & $\mathbf{4 4 , 8}$ \\
\hline Carbamazepin & $\mathbf{1 6}$ & $\mathbf{9 , 3}$ \\
\hline Asam Valproat & $\mathbf{6}$ & $\mathbf{3 , 5}$ \\
\hline Fenitoin dan Carbamazepin & $\mathbf{4 8}$ & $\mathbf{2 7 , 9}$ \\
\hline Fenitoin dan Asam Valproat & $\mathbf{8}$ & $\mathbf{4 , 7}$ \\
\hline Asam Valproat dan Carbamazepin & $\mathbf{1 1}$ & $\mathbf{6 , 4}$ \\
\hline Gabapentin dan Asam Valproat & $\mathbf{6}$ & $\mathbf{3 , 5}$ \\
\hline Total & $\mathbf{1 7 2}$ & $\mathbf{1 0 0}$ \\
\hline
\end{tabular}

\section{PEMBAHASAN}

Penelitian yang dilakukan Nihon pada tahun 2014 yang menemukan jumlah pasien epilepsi menurut jenis kelamin hampir seimbang antara pasien perempuan dan laki-laki (Nihon, 2014). Walaupun demikian, perempuan dapat lebih tinggi berisiko menderita epilepsi dibandingkan dengan laki-laki. Hal tersebut diduga pengaruh hormon pada perempuan berperan penting dalam insiden terjadinya epilepsi. Tidak hanya itu, perempuan khususnya ibu hamil yang menderita epilepsi merasa khawatir terhadap dampak obat anti epilepsi pada janinnya, sehingga ibu hamil cenderung tidak meminum obatnya yang berakibat peningkatan serangan 
epilepsi pada ibu hamil (Luef \& Taubøll, 2015).

Pengaruh Ovarian Steroid Hormones pada perempuan yang dapat mengubah eksitasi pada neuron di sistem saraf pusat. Hormon estrogen diketahui dapat menurunkan sifat inhibisi pada reseptor neurotransmiter GABA terutama GABAA dengan mengubah daya konduksi ion $\mathrm{Cl}^{-}$dan meningkatkan sifat eksitasi pada reseptor glutamat dengan bersifat agonis terhadap reseptor NMDA, sehingga terjadilah peningkatan eksitasi pada neuron otak yang kemudian akan potensial mencetuskan terjadinya bangkitan. Pada hormon progesteron yang diketahui lebih banyak terdapat pada laki-laki dapat meningkatkan aktivitas inhibitor yang dimediasi oleh neurotransmiter GABA, meningkatkan sintesis GABA, dan meningkatkan kecepatan pembuatan sub unit reseptor GABAA. Perempuan dengan epilepsi mungkin akan mengalami perubahan kejang saat masa pubertas, selama siklus menstruasi dan saat menopause yang juga terkait dengan perubahan level dari hormon estrogen dalam tubuhnya (McHugh \& Delanty, 2008).

Sesuai dengan laporan WHO mengenai prevalensi epilepsi di negara berkembang, terbanyak pada usia dekade dua sampai dekade lima. Diperkirakan hal ini terjadi karena adanya perbedaan faktor risiko yang mempengaruhi seperti pola hidup untuk kesehatan dan ekonomi, sehingga menyebabkan tingkat harapan hidup lebih rendah di negara berkembang (Maryam dkk., 2018; WHO, 2019). Sejalan dengan penelitian yang dilakukan oleh Sarabjot dkk. didapatkan bahwa dari 100 pasien epilepsi, 38\% berada dalam kelompok usia dewasa menengah yaitu 21-40 tahun. Stroke adalah etiologi yang paling umum pada pasien dengan kelompok usia tersebut (Sarabjot dkk., 2018).

Hal ini dapat dihubungkan dengan tingginya usia dewasa terhadap penyebab terjadinya penyakit, beberapa faktornya adalah stres, hormonal, penyakit cerebrovascular, dan kejadian trauma kepala. Stres diduga mempunyai pengaruh terhadap terjadinya serangan epilepsi. Pada keadaan stres akan terjadi hiperventilasi dimana kadar $\mathrm{CO}_{2}$ dalam darah meningkat yang akan menyebabkan sel otak melepaskan letupan muatan listrik yang abnormal diluar kehendak. Mediator stres seperti Corticosteroid dan Corticotropin Releasing Hormone $(\mathrm{CRH})$ berkontribusi terhadap kejadian epilepsi. Hormon cotricosteroid dengan cepat akan meningkatkan kadar $\mathrm{Cl}$ - yang masuk menembus membran neuron, hal ini dapat menyebabkan cedera pada saraf kemudian akan terjadi depolarisasi. Kadar streoid yang tinggi dapat meningkatkan dan mempercepat patogenesis epilepsi. $\mathrm{CRH}$ akan meningkatkan letupan spontan dan kemudian akan terjadi penekanan hiperpolarisasi setelah terjadinya letupan potensial aksi yang berlebihan (Maryam dkk., 2018).

Hasil ini sesuai dengan penelitian yang dilakukan Maryam dkk. (2018), diperoleh jenis bangkitan umum sebanyak 33 pasien $(47.1 \%)$, sedangkan bangkitan parsial sebanyak 20 pasien (28.6\%). Sejalan pula dengan penelitian yang dilakukan Gunawan dan Stephanie (2017), diketahui tipe bangkitan umum lebih banyak terjadi pada pasien epilepsi. Epilepsi umum banyak terjadi pada awal usia dewasa, selain itu epilepsi parsial lebih banyak terjadi. Epilepsi parsial juga merupakan jenis epilepsi yang paling banyak ditemukan pada kelompok onset usia tua akibat tingginya insiden stroke, gangguan metabolik sistemik, hematoma subdural, infeksi SSP, kelainan degeneratif dan keganasan (Gunawan dan Stephanie, 2017).

Etiologi simptomatik paling banyak juga ditemukan pada penelitian yang dilakukan Maryam dkk. (2016), yaitu 59 pasien $(84.3 \%)$, sedangkan etiologi jenis idiopatik berjumlah 11 pasien (15.7\%) 
(Maryam dkk., 2018). Pasien dengan riwayat trauma kepala adalah etiologi epilepsi yang cukup luas terjadi di negara maju maupun berkembang (Bhalla, 2011). Jumlah kasus awal epilepsi salah satunya banyak terjadi pada orang dewasa karena rentan terhadap paparan yang menyebabkan epilepsi simptomatik seperti trauma kepala, infeksi, post-stroke, gangguan metabolik dan keracunan, sedangkan kebanyakan epilepsi parsial pada awal usia adalah idiopatik (Nwani, 2016).

Pada penelitian yang dilakukan Khasanah dkk. menunjukan penyandang epilepsi paling banyak menggunakan OAE fenitoin dan diikuti dengan karbamazepin secara monoterapi sebanyak 88 pasien $(88 \%)$ dan pasien yang menggunakan politerapi hanya sebanyak 12 pasien (12\%) (Khasanah dkk., 2015). Hasil tersebut diperkuat dengan penelitian yang dilakukan oleh Hasibuan tahun tentang terapi pengobatan paling banyak digunakan, yaitu fenitoin $(53,2 \%)$, lalu diikuti oleh asam valproat $(21,5 \%)$ dan karbamazepin (12\%) (Hasibuan dkk., 2016).

Pemberian obat tunggal atau monoterapi sangat sesuai jika digunakan dengan dosis yang cukup, secara bertahap dari dosis rendah dan dapat ditingkatkan sehingga dapat mengendalikan bangkitan epilepsi. Monoterapi OAE juga lebih disukai oleh populasi tertentu baik itu pasien khusus termasuk perempuan, lansia dan pasien dengan kondisi komorbid. Penelitian yang dilakukan Ruslami pada tahun 2016 menyatakan bahwa karakteristik suatu OAE yang ideal dan yang diinginkan adalah mempunyai bioavailabilitas yang tinggi, mencapai keadaan steady-state dengan cepat, kinetiknya bersifat linear (konsentrasi dalam darah yang berkaitan dengan efek samping dapat diprediksi dari dosis yang diberikan), ikatan dengan protein rendah, waktu paruh yang memungkinkan obat diberikan 1-2 kali per hari, tidak dimetabolisme, dan tidak ada potensi interaksi obat. OAE generasi pertama umumnya mempunyai karakteristik berupa absorpsi oral yang cukup baik, mempunyai kinetik non-linear, ikatan dengan protein tidak kuat (kecuali fenitoin dan asam valproat), di metabolisme di hepar dan diekskresi melalui sistem bilierhepatik, mempunyai waktu paruh yang panjang, dan berpotensi menimbulkan interaksi obat. Sedangkan beberapa OAE generasi kedua mempunyai profil farmakokinetik yang lebih baik dan ikatan dengan protein minimal (Louis \& Rosenfeld, 2009; Ruslami \& Bisri, 2016).

\section{KESIMPULAN}

Berdasarkan hasil penelitian yang telah dilakukan tentang karakteristik pada pasien epilepsi di Poliklinik Saraf Rumah Sakit di Kota Jambi, diperoleh kesimpulan jenis kelamin sampel penelitian terbanyak adalah perempuan dengan usia 21-31 tahun. Jenis bangkitan yang sering terjadi adalah bangkitan umum dengan etiologi simptomatik dan menggunakan obat anti epilepsi (OAE) monoterapi fenitoin.

\section{SARAN}

Penulis menyarankan adanya penelitian lebih lanjut dengan variabel yang lebih luas, perolehan data tidak hanya data sekunder, tetapi juga primer serta mengembangkan penelitian ini menggunakan rancangan dan metode yang lain agar dapat diketahui hubungan antar variabelnya.

\section{DAFTAR PUSTAKA}

Bhalla, D., Godet, B., Druet-Cabanac, M., Preux, P. (2011). Etiologies of epilepsy: A comprehensive review. Expert review of neurotherapeutics. 11:861-76.

Gunawan, P.Y., Stephanie, E.D. (2014). Karakteristik pasien epilepsi di rumah sakit siloam lippo village, tahun 2013. Medicinus 4:2-5.

Hasibuan, M., Mahama, C., Tumewan, R. (2016). Profil penyandang epilepsi di poliklinik saraf rsup 
prof.dr.r.d. kandau manado periode juli 2015-juni. J e-Clin $4(2): 1-5$.

Khasanah, R., Mahama, C., Runtuwene, T. (2015). Profil penyandang epilepsi di poliklinik saraf rsup prof.dr.r.d. kandau manado periode juni 2013-mei 2014. J e-Clin 3:472-6.

Louis, E.K., Rosenfeld, W.E. (2009). Antiepileptic drug monotherapy: The initial approach in epilepsy management.

Curr Neuropharmacol. 7(2):77-82.

Luef G., Taubøll E. (2015). Gender issues in epilepsy - difference in management of epilepsy. Seizure 28:1-2.

Maryam I.S., Wijayanti S.A.I., dkk. (2018). Karakteristik klinis pasien epilepsi di poliklinik saraf rsup sanglah denpasar. Callosum Neurology 1(3):89-94.

McHugh, J.C., Delanty, N. (2008). Chapter 2 epidemiology and classification of epilepsy: Gender comparisons. Int Rev Neurobiol 83:11-26.

Nihon R. (2014). Epidemiology and cause of epilepsy. Jap J Clin Med 72(5):785-9.

Nwani, P.O., Nwosu, M.C., Nwosu, M,N. (2016). Epidemiology of acute symptomatic seizures among adult medical admissions. Epilepsy Res Treat 2016:4718372.

PERDOSSI. (2012). Pedoman tatalaksana epilepsi: Kelompok studi epilepsi perhimpunan dokter spesialis saraf indonesia. Edisi ke-4. Harsono, Kustiowati, Gunadharma S, penyunting. Surabaya: Airlangga University Press.
PERDOSSI. (2016). Pedoman tatalaksana epilepsi: Kelompok studi epilepsi perhimpunan dokter spesialis saraf indonesia. Edisi ke-5. Kusumastuti K, Gunadharma S, Kustiowati E, penyunting. Surabaya: Airlangga University Press.

Robert S., Walter E., Warren B., dkk. (2005). Epileptic seizures and epilepsy: definition proposed by the international league againts epilepsy (ilae) and the international bureau for epilepsy (ibe). Epilepsia 46(4):470-472.

Ruslami, R., Bisri, T. (2016). Penggunaan obat anti epilepsi untuk terapi profilaksis bangkitan pada cedera otak traumatik. J neuroanestesi Indones 4(1):77-85.

Sarabjot, K., Ravinder, G., Ranabis, P. (2018). Adult onset seizure: Clinical, etiological, and radiological profile. J Fam Med Prim Care 7:191-197.

Vonck, K., deHerdt, V. Sprenger, M., Ben-Menachem, E. (2012). Neurostimulation for epilepsy. Dalam: Stefan $\mathrm{H}$, Theodore $\mathrm{WH}$, penyunting. Handbook of Clinical Neurology. Birmingham: Elsevier Inc.

World Health Organization (WHO). (2019). Epilepsy Fact Sheet. [diunduh 1 Maret 2011]. Tersedia dari: https://www.who.int/news-room /fact-sheets/detail/epilepsy 